Biannual Research Journal Grassroots

Vol.55, No.II, 2021: 242-254

Grassroots

\title{
KASHMIRI MUSLIM'S DIASPORA IN PUNJAB UNDER MAHARAJA RANJIT SINGH
}

\author{
Dr. Robina Yasmin \\ Assistant Professor, Department of Pakistan Studies, \\ The Islamia University, Bahawalpur \\ Email: robinashoebsyed@gmail.com \\ Dr. Fakhar Bilal \\ Assistant Professor, Department of History, Quaid-i-Azam University, Islamabad \\ Email:fakhar.qau@gmail.com \\ Dr. Turab ul Hassan \\ Assistant Professor, Bahauddin Zakariya University, Multan \\ Email: turabsargana@gmail.com
}

\begin{abstract}
History of Kashmir is full of tales of terror and oppression. For centuries, despite change of rulers and reigns, sufferings of Kashmiris have continued unabated. Sikh rule under Maharaja Ranjit Singh is particularly, accused of persecution of Kashmiris. This persistent privation forced many Kashmiris to leave their homeland and settle in other areas of the Punjab during Sikh rule. Maharaja Ranjit Singh replaced eight governors one after the other, mainly on account of charges of persecuting Kashmiris however; neither miseries of Kashmiris halted nor their migration to other parts of Punjab. In addition to this 'push', establishment of factory of Kashmiri shawls and several residential colonies in Lahore and other parts of Punjab, also attracted lots of Kashmiris to Punjab where better prospects of employment, habitation and self-esteem existed. The current study therefore, would mainly focus on various 'push and pull'factors that forced Kashmiris to abandon their homes and settle in various parts of the Punjab during the Sikh rule. Additionally, the study will also explore, in the light of primary and secondary sources, the existing narrative against Maharaja Ranjit Singh for persecuting and forcing relocation of Kashmiris, and see if these allegations hold some ground or these are mere stereotypes and part of some larger conspiracy theory to divide the Muslims and the Sikh communities.
\end{abstract}

Keywords: Kashmir, Maharaja Ranjit Singh, Sikh Rule, Muslims, Punjab.

\section{INTRODUCTION}

By the early $19^{\text {th }}$ century, the Afghans were driven out of the Punjab and their Cis-lndus territories were also gradually encroached upon by the growing Sikh power in the Punjab. Maharaja Ranjit Singh 
was eager to expand his Kingdom in North-West. Although, Kashmir fell into the hands of the Sikhs in 1819 however; the Kashmiris had suffered under the cruel rule of the Afghans well before the advent of the Sikhs in Kashmir (Khushwant Singh, 2004:3).

G.M.D. Sufi writes about the condition of the local people, who were mostly Muslims. "The Afghans signalized their stay by roughness and harshness. Their chief victims were the bold Chaks and the Shias. The Sunnis did not fare better. It is said of the Afghans that they thought no more of cutting off heads than of plucking flowers" (G.M.D.Sufi, 1949:807-8).

In the last decades of the $17^{\text {th }}$ century during the reign of Aurangzeb, the Mughal empire had started declining. After his death in 1707, ambitious regional chieftains consolidated power in their respective territories and the links with the central Mughal command started weakening ${ }^{1}$. Northern India was a sea of chaos. The misrule by the Mughal satraps made it possible for Ahmad Shah Abdali, the founder of the Durrani empire in Afghanistan, to consolidate power. Abdali raided India at least eight times between 1748 and 1767. Kashmir was conquered in the course of these raids, in 1752.

Abdullah Khan lshikAqasi, a commander sent by Ahmad Shah Abdali, defeated the remnants of the Mughal army in 1752, bringing an end to Mughal rule in Kashmir. Due to political instability in Kabul, the Durrani Subedars in charge of Kashmir kept changing, and 28 of them ruled Kashmir in the course of 67 years of Afghan rule. If Kashmiris had any hopes that Kabul's rule would better their lives, those were quickly dashed. Though there were no external invasions, the period was marked by oppression, high taxation and governors who were variously cruel, brutal or indifferent, according to several historical accounts.

The Sikhs and the Afghans fought a number of battles during the reign of Maharaja Ranjit Singh. After the fall of Atta Muhammad

\footnotetext{
${ }^{1}$ After the Mughals: How the Afghan, Sikh and Dogra rule shaped Jammu and Kashmir, Retrieved from: https://www.timesnownews.com/india/article/kashmirjammu-jk-mughals-afghan-sikh-dogra-ranjit-singh-british-ahmad-shah-abdalidurrani-aurangzeb-gulab-hari-pandits/300092\#: :text $=\operatorname{In} \% 201819 \% 2 \mathrm{C} \% 20$ Kashmir\%20was\%20annexed,Mughal $\% 20$ empire $\% 20$ had $\% 20$ started $\% 20$ declini ng on 24-11-2019.
} 
Khan ${ }^{2}$, Fateh Khan ${ }^{3}$ appointed his other brother Muhammad Azim Khan as the Governor of Kashmir (Khushwant Singh, 2004:237). He was courageous and intelligent and kept a strong hold on Kashmir. This worried Ranjit Singh, who decided to take over Kashmir as soon as possible. In fact, the fort of Attock was under threat because of the grip of the Afghans on Kashmir. The Maharajah planned to attack Kashmir immediately after the battle of Khizru and set off in October 1813. He ordered all sardars to come together in Sialkot, but a heavy snowfall forced him to return to Lahore. In 1814, he again decided to attack Kashmir. He divided the Sikh force into two parts, one supervised by himself and the other under the command of Diwan Ram Deyal, the grandson of Diwan Mohkam Chand. Diwan Ram Deyal reached Behram Gullah on 18 June 1814. During this time, many problems arose between the Sikhs and the Afghans, which the Sikhs successfully overcame. On 24 June, the Sikh forces faced the Afghans and won the battle, but in the next fight the Afghans defeated the Sikh army. Ranjit Singh could not reach Ram Deyal because of excessive rain and, despite his best efforts to reach Kashmir, had to return to Lahore. Attacks by Azim Khan forced Ram Deyal and his army to stay outside Kashmir. Due to this failure, the areas around Kashmir remained out of Lahore's direct control (Sohan Lal Suri, 2002:84). However, Ranjit Singh's conquests of Rajodi and Bhambhar re-established his control over these areas. Despite the setbacks, Ranjit Singh never lost his desire to capture Kashmir, and he got his chance in 1819.

After Azim Khan ${ }^{4}$ also left for Kabul with the major part of his army, the strength and hold of the Afghan forces were reduced, and Ranjit Singh took full advantage of the situation to attack Kashmir. The leading half his army was under the command of Prince Kharak Singh, and Ranjit Singh led the second half. He deputed a number of soldiers for speedy delivery of messages across the whole rank and file of the army (Khushwant Singh, 2004:255). The Sikh army became stronger when the forces of Sultan Khan, ruler of Bhimbhar, joined the Maharaja. Obtaining help from Bhimbhar was a strategic and bold

${ }^{2}$ He was the brother of Fateh Khan and ruler of Kashmir at that time.

3 Fateh Khan Barakzi was the minister of Shah Mahmood, who was the grandson of Ahmad Shah Abdali, and the ruler of Kabul.

4 The than ruler of Kashmir and brother of Fateh Khan. 
decision, which earned Ranjit Singh a great victory (Ibid). The Sikh forces won a battle at Rajori, and then set off for the next destination under the command of Prince Kharak Singh, accompanied by Misr Diwan Chand. After passing through rough, tough terrain, the army finally reached and captured Poonch. This put the Sikh forces directly in front of the Afghans on the field of PanjPir ${ }^{5}$. The Afghans lost this battle and the Sikhs reached Aliabad, where they now faced the army of Jabbar Khan, the brother of Azim Khan. Both forces fought fearlessly, but the Sikh army emerged victorious largely due to the military skills of Phula Singh, one of Ranjit Singh's able generals. The Afghan forces ran away and the Sikhs collected much booty. Jabbar Khan retreated first to Sri Nagarand from there through Bara Mullah to Peshawar. On 4 July 1819, the Sikh forces entered Sri Nagar, under strict orders, enforced by Misr Diwan Chand (G.M.d.Sufi, 1949:721), not to harm the citizens in any way. When it was announced that the people were to be given an amnesty, the population was overjoyed and happily accepted the Sikh rule. Misr Diwan Chand was given the title of Zafar-e-Jang and was nominated Governor of Kashmir. Fakir Azizuddin and Reza Ansari were sent to study the climate of the valley, along with Diwan Devi Das to organize the system of revenue. The conquest of Kashmir naturally was an extraordinary addition to the kingdom of Maharaja Ranjit Singh, leading to increased revenue. In fact, he told C.M Wade of the British political department that Kashmir was the most productive of all his provinces, with annual revenue of Rs. 25 lakh. $^{6}$

In 1819, Kashmir was annexed by Ranjit Singh's forces, thus ending Afghan rule and more than four centuries years of Muslim rule in the Valley. The conquest of Kashmir was a significant addition to the Sikh Kingdom mainly for its riches and scenic beauty. In fact, Kashmir was the richest province of the Sikh Kingdom next only to Multan.

Sikh rule in Kashmir lasted for some twenty-seven years. During this period ten governors were appointed to administer the valley. Two were Muslims, three Sikhs and five Hindus: Misr Diwan Chand,

\footnotetext{
5 A magnificent and famous touring place in northern part of Pakistan endowed with the mountains, rocks, pine trees, valleys and fountains.

6 The Lahore Darbar: In the Light of the Correspondence of Sir C.M. Wade (1823-49) (Lahore: Punjab Government Records Office, 1930).
} 
Diwan Moti Ram, Sardar Hari Singh Nalwa, Diwan Chunni Lal, Diwan Kirpa Ram, Bhīma Singh Ardali, Prince Sher Singh, Colonel Mahan Singh, Sheikh Ghulam Muhaiy-ud-Din and Sheikh Imamuddin. However, because of their corruption, Ranjit Singh was not happy with the performance of any of his governors. He once commented that all the people he had sent to the beautiful valley of Kashmir proved to be haramzadaz (bastards), adding that he should have sent one of his sons or himself for the administration. This was the very reason that he kept on changing the governors on the reports from Kashmir.

The Sikh rulers were generally tolerant towards different faiths, but some decisions rankled the majority Muslim population in the Valley. For instance, Diwan Moti Ram, the first governor under Sikh rule (incidentally a Hindu), called for halting of public azan and Friday prayers in the Jama Masjid. Because of these incidents some historians have levelled a number of allegations against Maharaja Ranjit Singh for maltreating Kashmiris. European writers such as William Moorcroft, Victor Jacquemont, G. T. Vigne, Charles Hugeland Henderson, who toured Kashmir during the Sikh rule, undertook detailed study of Kashmiri people, places, agriculture, art and industries. Most of these travel accounts are politically motivated and highly critical of Maharaja Ranjit Singh's rule. Needless to highlight, a group of authors of history of Kashmir and European travellers had their own reasons for presenting Sikh rule negatively, however; let's examine that was it a fact, that Maharaja's rule helped improve the economic conditions of Kashmir and Kashmiris or it just worsened the Muslims condition more than it was before. That said, the Sikhs ensured there was adequate representation of Hindus, Muslims and Sikhs in the administration.

Sikh rule over Kashmir lasted for over 27 years. During this period Maharaja Ranjit Singh ruled over Kashmir through his governors. In all, ten governors were appointed by the Lahore Durbar between 1819-1846 and one of them, Dewan Moti Ram held the office of governorship twice (Sohan Lal Suri, 2002:355). In order to give my august audience a sense of political situation in Kashmir I would very briefly discus the tenure and tenor of some of the governors of Kashmir who were appointed and subsequently removed from the office of governor for their poor and unjust administration. 
The Maharaja appointed Dewan Moti Ram (1819-1820) and then (1821-1824) as the first Governor of Kashmir. He served twice and was amongst the most respected, reliable and capable officers of Sikh administration (Amarnath, 1928:85). However, despite all his loyalty and competence, Maharaja Ranjit Singh didn't hesitate to call him back and reprimand him for his repressive policies against the Kashmiris. This shows Maharaja's sincere intents for the welfare of the Kashmir and Kashmiris who were predominantly Muslims.

Sardar Hari Singh Nalwa's (1820-1821) appointment as Governor of Kashmir was questioned by Fakir Azizuddin on the grounds that, extraordinary general though he was, however; as a leader and administrator, his policies and administration was reckless and damaging for all: Kashmir, Kashmiris and Khalsa state as well. In light of Fakir Azizuddin's advice, the Maharaja removed Hari Singh Nalwa and appointed a more thoughtful individual as governor of Kashmir despite the fact that Hari Singh Nalwa collected huge revenue for the Sikh state during his tenure as governor of Kashmir (G.T.Vigne, 1840:308).

During the governorship of Diwan Chunni Lal,(1824-1826), a strict Sardar Kumedan Gurmukh Singh was appointed as the head of revenue collection and administration. During Chunni Lal's governorship, Khwaja Muhaiy-ud-Din, a respectable Kashmiri Muslims was falsely implicated and treated inhumanly on false evidence in a cow-killing case. When Ranjit Singh heard reports of their cruelty, he recalled both of them back to Lahore. He, even appointed an enquiry committee, consisting of three representatives of the Hindus, the Sikhs and the Muslims for conducting a probe into the unfortunate incident (K.S.Duggal, 1989:20).

The Maharaja appointed Dewan Kirpa Ram (1826-1830), Governor of Kashmir who ruled the province better than had his father, Moti Ram. When Kirpa Ram was the governor of Kashmir, he introduced different types of shawls; some were even named after him, like Kirpa Ram's Doshala. He also introduced different types of Kashmiri carpets. However, when complaints about his harsh policies reached Maharaja Ranjit Singh he was recalled immediately (Radha Sharma, 2001:15).

This is a very brief description of governance and political conditions of Kashmir. Every new governor despite strict command of 
the Maharaja and knowledge of the fate of past governors, continued their malpractices and bad governance only to face the same results again, and again. Resultantly, Ranjit Singh kept on replacing the governors who maltreated the people administratively, economically and socially, forcing many of them to migrate to other parts of the Punjab for better employment. This means at least that other parts of the Punjab were considered safe economically as well as socially.

The administrative record of these governors is replete with flaws and malpractices except one Mahan Singh who was remembered by the Kashmiris for his benevolent policies and administration. For his good governance and enlightened administration, he continued as governor of Kashmir even after the death of Maharaja Ranjit Singh. Col. Mahan Singh, Governor of Kashmir did his best for the welfare of the Kashmiris. There are several stories about his justice and fair treatment (William Moorcroft and Trebeck George, 1841:123-4). He tried to revive trade and industry in Kashmir, which largely benefitted the Muslims.

The short periods of office resulted mainly from the complaints of the local people of their brutality, and especially the dissatisfaction and uneasiness of the Muslims. After hearing the complaints of the Muslims, Ranjit Singh in 1833 sent the French officer General Allard to Kashmir with the direction to investigate the complaints and assess the governance. In the light of his findings, Ranjit Singh introduced reforms and appointed Colonel Mahan Singh, who proved to be a good administrator and improved the welfare of the people.

This terrible famine hit hard Kashmir, which reduced the population to less than half. During that period, Jamadar Khushhal Khan collected the revenue from the people and presented it to the Maharaja who was very angry with Jamadar for taxing the people of Kashmir during difficult times. Subsequently all the money was returned and distributed among the Kashmiris. Special convoys of food and grain were dispatched to Kashmir. In order to mitigate the ravages of famine, the Sikh state also advanced interest-free loans to Kashmiris for improvement in agriculture and life of Kashmiris. Moreover, after this famine, Maharaja Ranjit Singh also reduced the land tax to half the produce of the land.

Exploring newer economic opportunities: Beginning of Kashmiri Diaspora: Shawl making was one of Kashmir's main 
sources of revenue. During the Mughal and Afghan rule, the shawl industries of Kashmir were at their top and this factor contributed towards the growth of urban population in the valley (William Moorcroft and Trebeck George, 1841:123-4). Primarily, Muslims dominated the shawl industry in Kashmir. When Maharaja Ranjit Singh annexed the valley to his kingdom in 1819, there existed 84 varieties of crafts and trades in the city of Srinagar alone.

Kashmiri shawls were sent to the Lahore Darbar, and it is reported that during the period of Maharaja Ranjit Singh, the workers received full benefit from their work. In response to a report by C.M. Wade in which he mentioned the heavy taxes which were imposed on the weavers under Sikh Rule, Jean Marie Lafont has given a detailed note with the figures showing that it was not true because the weavers were getting their due share (Lafont, 2002:88-89).

A key factor in the depressed economic condition of the Muslims was the sequence of famines that hit Kashmir one after the other. Maharaja Ranjit Singh tried to mitigate the impact of natural calamities of repeated famine and disease, yet could not do it fully. In fact, due to great famine of 1832, thousands of workmen died of hunger and consequently trade and industries suffered badly and the proportion of industrial population recorded a steep fall. The flourishing shawls industries of Kashmir could not recover from the shock of this famine in spite, of the best efforts made by Maharaja Ranjit Singh to put it on the sound footings.

Walter Hamilton viewed Amritsar and Kashmir as grand centres of exchange for shawls and saffron. All these things were additionally traded to other parts of India, and shawls from Kashmir, Amritsar and Gujrat to Europe.

The hosiery industry of United Punjab was initially set up by Muslim Kashmiri migrants who had left their homeland in 1830s. They introduced new variety of woolen shawls in Punjab that made it very popular brand across the country. Some writers have written that Indian elite and the British officers liked these woolen brands. The fame of the shawls among British officers helped to introduce the products into Western Market that earned its appreciation there as well. The working of the industry included making 'Loongi and Patkas'. 
These people also provided the Army uniform and badges to the soldiers. However, some accounts suggest that Muslims did not own hosiery industry at large scale and their status was of workers. Still it is important to mention that all the working and management was in control of Muslims and they used their experience to flourish hosiery Industry (Datta, Vishwa N., 1986:442-60).

However, in spite of the flourishing trade and the abundance of agricultural output, the majority of Kashmiris remained under acute poverty in this land of plenty largely because of bad governance and poor state policies which forced Kashmiris to leave Kashmir in search greener pasture (G.T.Vigne, 1840:308).

In Amritsar and Lahore there were several factories for shawl production. The first factory for Kashmiri shawls was established in Amritsar as a result of migration of Kashmiris Muslims to Amritsar because of the harsh behaviour of Jamadar Khushhal Singh. The Kashmiris Muslims left Kashmir and set up their businesses in Amritsar and Lahore. This confirms that the circumstances and life for the Muslim Kashmiris were better in other parts of Punjab, it also confirms that maltreatment of local Kashmiris was the outcome of the personal policies of the individual governors and not because of Maharaja Ranjit Singh's Sarkar-e-Khalsa and its policies, this also shows that how political conditions forced Kashmiris to leave Kashmir and how availability of economic opportunities in other parts of Punjab proved to be a pull factor for the Kashmiris. Had this been under the command of Maharaja Ranjit Singh, the Kashmiris would have not chosen Lahore or Amritsar as their business and living abodes. Ranjit Singh also encouraged the shawl industry by providing grants and loans in cash and kind (wool) to the weavers.

During the times of Maharaja Ranjit Singh, number of Kashmiris settled in various areas in Lahore. In the presence of ever-increasing economic activities, these areas developed considerably. As a matter of fact, Hordes of Kashmiris headed settled in Gowalmandi and Kashmiri Bazar in the walled city Lahore bringing with them samples of delightful Kashmiri cuisine and spices. Today the same flavors have been carried forwarded over the decades to create a fine blend of spicy Punjabi dishes and aromatic Kashmiri savor (Richard Temple, 1981:145).

\section{A SUCCESS STORY}


It is very interesting to narrate here the story of a very poor boy who migrated from Kashmir to Punjab, Lahore with his mother, during the Sikh Period, named Mian Muhammad Sultan, famously known as Thekadar Sultan. One can read about his life and achievement in "Halat-e-Mashahir-e-Kashmir" and "Tariekh-e-Aqwam-e-Kashmir". He started his early life as a laborer but with a passage of time he became so rich and popular in Lahore that people used to call him "Lahore ka Betaj Badshah". For his services he even won a horse and gifts from Maharaja Ranjit Singh and Sher Singh also. He was not an educated man; he got the contracts of making buildings from the Sikh Darbar and even during the British period. The Railway station of Lahore was first constructed by him. He was a very generous person, and, in his generosity, he never differentiates between the Hindus, Sikh and the Muslims. He built a 'Sarai' outside the Delhi Darwaza near the walled city for the poor people and never took any money for the services (https://dailytimes.com.pk/245850/haveli-of-the-sultancontractor-a-hidden-gem-of-history/).

\section{CONCLUSION}

Maharaja Ranjit Singh always remained deeply concerned over ever deteriorating conditions of the valley. He wanted to put Kashmir back to its former prosperity and affluence. To deal with Kashmiris whose large Muslim population was under lots of distress and had also been unfairly labeled as 'adversary' being once the ruler of the valley, could have been a challenge for any ruler; it really, was so for Maharaja Ranjit Singh. It needed lots of statesmanship, political wisdom, and administrative benevolence to govern over 'Jannat Nazeeer' Kashmir valley while dealing with socioeconomic and cultural imperatives of Kashmir.

Hence, he hardly remained satisfied with his governors in Kashmir. They proved to be reckless, unfair and fond of malpractices. The Maharaja removed one governor after the other on the sheer complaints of their repressive policies and lack of benevolence. The Maharaja, in pursuit of his desire to bring about change in Kashmir, always remained concerned about the performance of his governors. He once commented that all the people he had sent to the beautiful valley of Kashmir proved to be 'disasters', adding that he should have sent one of his sons or himself for the administration. 
When the local Sardars failed, the Maharaja also deputed his French officer to study Kashmir and present a diagnostic report on the waning conditions of the valley. In the light of the recommendation of the French officer, the Maharaja designed a new policy to deal with the miseries of the Kashmiri people. Col. Mahan Singh was appointed as governor of Kashmir to implement the new policy for the valley of Kashmir. As a result of the new policy and its better implementation, the Shawl industry revived, production resumed and valley prospered again. The new governor used his political and administrative wisdom with good heart and compassion for the Kashmiris which led to wellbeing of the people of Kashmir.

This is part of living history, that the Maharaja removed governors of Kashmir only for their malpractices and repressive administration which is alone adequate to challenge the long list of allegations against the Maharaja, of oppression of Kashmir. The Maharaja had constantly been monitoring their performance and reprimanding them for their bad governance.

In fact, the poor, unfair and corrupt policies and practices of the Sikh governors, and one after the other natural calamities such as epidemics, storms, mainly remained responsible for the failing economic and social conditions of Kashmir and its people.

This was his desire to bring prosperity to Kashmir, that he kept on changing the governors for their poor performance and repressive policies forcing many of them to migrate to other parts of the Punjab for better employment. This means at least that other parts of the Punjab were considered safe economically as well as socially.

\section{REFERENCES}

Amarnath, (1928). Zafarnama-i-Ranjit Singh (Persian), ed. Sita Ram Kohli (Lahore: University of the Punjab) and Sohan Lal Suri, Umdat-utTawarikh.

Datta, Vishwa N. (1986). Panjabi refugees and the urban development of Greater Delhi. Delhi Through the Ages. Essays in Urban History, Culture and Society. Oxford University Press, Delhi, pp.442-460. 
Fauja Singh and A.C. Arora, (eds.) (1984). Maharaja Ranjit Singh: Politics, Society, and Economy (Patiala: Publication Bureau, Punjabi University), p.149.

G.M.D. Sufi, (1949). Kashīr Being a History of Kashmīr from the Earliest Times to Our Own with a Bibliography and with Plates Including Maps. $2^{\text {nd }}$ ed. (Lahore: University of the Panjab), pp.707-8.

G.T. Vigne, (1840). A Personal Narrative of a Visit to Ghazni, Cabul and Afghanistan and of a residence at the Court of Dost Mohammad Vol.1 (London: Whittakar and Company), p.308.

Govt. of Punjab (1884). Gazetteer Gujrat District 1883-84 (Lahore: Arya Press), p.120 and Grewal and Indu Banga, Early Nineteenth Century Punjab, 71.

Govt. of Punjab (1930). The Lahore Darbar: In the Light of the Correspondence of Sir C.M. Wade (1823-49) (Lahore: Records Office, 1930).

K.S. Duggal, (1989). Ranjit Singh a Secular Sikh Sovereign (Delhi: Abhinav Publications), p.20.

Khushwant Singh, (2004). A History of the Sikhs 1469-1838, Vol.1, Oxford University Press, p.255.

Lafont, Maharaja Ranjit Singh, (2002). Lord of the Five Rivers (New Delhi: Oxford University Press), pp.88,89.

Radha Sharma, (2001). The Lahore Darbar (Amritsar: Guru Nanak Dev University), p.15 and B.J. Hasrat, Life and Times of Maharaja Ranjit Singh, pp.263-265. ; See Also Grewal \& Indu Banga, (eds.), Maharaja Ranjit Singh and His Times (Amritsar: Department of History, Guru Nanak Dev University, 1980), p.71.

Richard Temple, (1981). The Legends of Punjab (Islamabad: Institute of Folk Heritage), p.145.

Sohan Lal Suri, (2002). Umdat-Ut-Tawarikh. Translated by V S Suri. Vol.2 (Amritsar: Guru Nanak Dev University), p.355. Also, Ali-ud-Din Mufti, Ibratnama, Ibratnameh: Ba-Ihtimam-i-Muhammad Baqir, Vol.2, (Lahore: The Panjabi Adabi Academy, 1961), p.519.

William Moorcroft and Trebeck George (1841). Travels in the Himalayan Provinces of Hindustan and the Panjab; in Ladakh and Kashmir; in Peshawar, Kabul, Kunduz and Bokhara.....from 1819 to 1825. (London: 1841), pp.123,124.

\section{WEBSITE LINKS}

https://dailytimes.com.pk/245850/haveli-of-the-sultan-contractor-a-hidden-gemof-history/

https://www.timesnownews.com/india/article/kashmir-jammu-jk-mughalsafghan-sikh-dogra-ranjit-singh-british-ahmad-shah-abdali-durraniaurangzeb-gulab-hari-pandits/300092\#: :text $=\mathrm{In} \% 201819 \% 2$ C\%20Kashmir\%20was\%20annexed,Mughal\%20empire\%20had\%20starte d\%20declining Retrieved on 24-11-2019. 
Biannual Research Journal Grassroots Vol.55, No.II: 242-254

https://www.timesnownews.com/india/article/kashmir-jammu-jk-mughalsafghan-sikh-dogra-ranjit-singh-british-ahmad-shah-abdali-durraniaurangzeb-gulab-hari

pandits/300092\#: : text $=$ In $\% 201819 \% 2 \mathrm{C} \% 20 \mathrm{Kashmir} \% 20 \mathrm{was} \% 20$ annexe d,Mughal\%20empire\%20had\%20started\%20declining Retrieved on 2411-2019.

https://www.timesnownews.com/india/article/kashmir-jammu-jk-mughalsafghan-sikh-dogra-ranjit-singh-british-ahmad-shah-abdali-durraniaurangzeb-gulab-hari pandits/300092\#: : text $=$ In $\% 201819 \% 2 \mathrm{C} \% 20 \mathrm{Kashmir} \% 20 \mathrm{was} \% 20$ annexe d,Mughal $\% 20$ empire $\% 20$ had $\% 20$ started $\% 20$ declining Retrieved on 24 11-2019. 